\title{
Pengembangan Media Pembelajaran Matematika Interaktif untuk Siswa Tunarungu
}

\author{
Fakhrur Razi, Makbul Muksar, Abd. Qohar \\ ${ }^{1}$ Pendidikan Matematika-Universitas Negeri Malang
}

\section{INFO ARTIKEL}

\section{Riwayat artikel:}

Diterima:10-05-2019

Disetujui: 22-06-2020

\section{Kata kunci:}

interactive mathematics learning; deaf students;

pembelajaran matematika interaktif;

siswa tunarungu

\section{Alamat Korespondensi:}

\section{Fakhrur Razi}

Pendidikan Matematika

Universitas Negeri Malang

Jalan Semarang 5 Malang

E-mail: fakhrur.razi.1703118@students.um.ac.id

Matematika merupakan pelajaran wajib yang dipelajari semua jenjang pendidikan dari sekolah dasar hingga menengah. Hal ini didasari pentingnya matematika bagi kehidupan siswa. Kebutuhan pada matematika akan terus meningkat dari waktu ke waktu sehingga siswa yang dapat mengaplikasikan matematika untuk mendapat peluang mencapai masa depan yang lebih baik (NCTM, 2000). Dalam teori matematika sekolah, ada prinsip yang dikenal dengan "prinsip kesetaraan". Prinsip ini berarti setiap siswa memiliki kesempatan yang sama untuk didukung dalam belajar matematika (NCTM, 2000). Dukes \& Smith (2009) menyatakan bahwa penyedia layanan pendidikan harus beratanggung jawab menjamin keragaman agar siswa mampu mengembangkan potensi dan berprestasi serta memberikan kontribusi bagi masyarakat. Hal ini bukan berarti setiap siswa harus mendapatkan perlakuan atau pengajaran yang sama, tetapi pengajaran matematika akan disesuaikan dengan kebutuhan masingmasing siswa.

Adanya kesetaraan dalam memperoleh pendidikan maka matematika dipelajari oleh semua siswa termasuk siswa berkebutuhan khusus. Salah satu bentuk siswa berkebutuhan khusus ialah siswa tunarugu yang mengalami gangguan pendengaran. WHO (2015) mengungkapkan bahwa gangguan pendengaran merupakan istilah yang menunjukkan ketidakmampuan mendengar dengan tingkat keparahan ringan sampai medalam. Seseorang yang mengalami gangguan ini biasanya menerima informasi melalui alat bantu dengar, ekspresi wajah, dan isyarat. Siswa tunarungu mengalami banyak masalah khusus dalam pembelajaran matematika akibat dari terhambatnya informasi. Menurut Ariapooran (2017), siswa tunarungu memiliki motivasi dan kemampuan matematika yang lebih rendah jika dibandingan dengan siswa normal. Sejalan dengan Kelly \& Gaustad (2006) yang menyatakan bahwa kemampuan bahasa siswa tunarungu berpengaruh signifikan terhadap kemampuan matematika siswa.

Peneliti melakukan pengamatan terhadap kemampuan matematika siswa tunarungu di kelas XI SMALB YPTB Malang. Soal-soal rutin mengenai luas dan keliling bangun datar (persegi panjang, persegi dan segitiga) diberikan kepada siswa. Hasilnya, siswa hanya mampu menjawab luas atau keliling bangun datar jika mereka mengingat rumusnya. Bahkan, tidak ada siswa yang menjawab dengan benar mengenai soal rutin luas dan keliling segitiga. Penyebab utama hal ini terjadi karena siswa 
tidak memahami konsep luas dan keliling bangun datar dengan baik karena lebih terbiasa menghafal rumus. Berdasarkan hasil wawancara dengan guru matematika di kelas, pembelajaran matematika pada siswa tunarungu masih menggunakan alat peraga dan belum menggunakan media interaktif berbantuan komputer yang digunakan secara mandiri. Guru biasanya menunjuk objek konkret dari bangun datar yang diajarkannya atau menggunakan layar dengan power point untuk membantu penjelasan materi. Guru juga menambahkan bahwa kendala bahasa merupakan hal yang paling utama dialami siswa selama pembelajaran sehingga banyak hambatan yang terjadi, seperti kesulitan siswa memahami penjelasan yang kompleks. Selama ini, guru hanya dapat menyampaikan pengenalan konsep bangun datar tanpa siswa membangun sendiri pengetahuan mereka.

Berdasarkan NCTM (2000), teknologi dapat membantu dalam mencapai kesetaraan dan harus dapat diakses oleh semua siswa. Penemuan baru dalam teknologi juga mampu membuka koneksi dan peluang untuk meningkatkan metode pengajaran. Passig (2000) mengklaim bahwa permainan teknologi virtual meningkatkan kemampuan berpikir pada anak-anak kesulitan mendengar. Sejalan dengan Shelton \& Parlin (2016) yang menyatakan bahwa guru merasa siswa lebih cepat dalam memahami pembelajaran dan siswa dapat meningkatkan hasil belajarnya setelah menggunakan media pembelajaran matematika berbasis aplikasi. Sehingga, suatu teknologi berupa media pembelajaran yang interaktif dapat menjadi salah satu solusi untuk membantu siswa tunarungu.

Techaraungrong dkk. (2017) melakukan desain dan pengujian terhadap media pembelajaran yang menunjukkan skor yang tinggi pada motivasi, pemahaman dan pembelajaran mandiri siswa tunarungu. Selain itu, Seo \& Woo (2010) menyebutkan pengembangan media pembelajaran menjadi sangat penting dalam memfasilitasi pembelajaran matematika siswa berkebutuhan khusus. Dengan begitu, diharapkan beberapa masalah pembelajaran yang dialami oleh siswa tunarungu dalam pembelajaran matematika dapat diselesaikan dengan penggunaan media pembelajaran.

Masalah-masalah yang dihadapi oleh siswa tunarungu berkaitan dengan lebih besarnya beban kognitif yang mereka hadapi dibandingkan siswa dengan pendengaran normal (Chen, 2014). Di antara beban kognitif tersebut ialah beban kognitif instrinsic, extranous dan germane (Mayer, 2014). Beban kognitif intrinsic merupakan beban yang diperoleh akibat kompleksitas materi yaitu seberapa banyak unsur yang ada dan bagaimana unsur-unsur tersebut saling terkait, beban kognitif extranous diperoleh akibat penyajian materi yang akan dipelajari dan beban kognitif germane terjadi secara otomatis jika memang ada muatan di working memory yang kosong akibat dari minimalnya beban kognitif intrinsic dan exstranous yang mana proses tersebut dapat dipengaruhi oleh motivasi dan sikap siswa terhadap materi yang dipelajari.

Perancangan media pembelajaran seharusnya didasari oleh prinsip-prinsip yang sesuai dengan kebutuhan siswa. Berdasarkan masalah-masalah yang dihadapi, siswa tunarungu tentu mengalami lebih banyak beban kognitif dibandingkan siswa normal. Sehingga, media pembelajaran dirancang agar mampu mengurangi beban kognitif extranous, mengontrol beban kognitif instrinsic dan membantu proses beban kognitif germane (Mayer \& Moreno, 2003). Prinsip-pronsip perancangan multimedia memang tidak dikhususkan untuk siswa tunarungu. Namun, (Cavender dkk., 2009) menyatakan bahwa strategi untuk menambahkan sumber visual merupakan cara yang baik dalam meningkatkatkan kemampuan siswa tunarungu. Maka, melalui ujicoba pada rancaagan media pembelajaran bagi siswa tunarungu diharapkan menghasilkan media pembelajaran matematika interaktif yang valid, praktis dan efektif bagi siswa tunarungu

\section{METODE}

Jenis penelitian ini adalah penelitian pengembangan. Penelitian ini dilaksanakan di kelas XI SMALB YPTB Kota Malang. Pada kelas tersebut terdapat lima orang siswa tunarungu. Pemilihan subjek dilakukan berdasarkan pertimbangan peneliti (purposive sampling) dengan alasan (1) subjek merupakan siswa tunarungu dengan tingkat yang sama dan (2) subjek mampu menggunakan komputer dengan baik.

Model pengembangan yang digunakan ialah model 4D, yaitu define (pendefenisian), design (perancangan), develop (pengembangan) dan tanpa memasukkan disseminate (penyebarluasan). Penelitian diaawali dengan mendefenisikan masalah yang berupa analisis awal akhir, analisis siswa, analisis tugas dan perumusan tujuan pembelajaran. Kemudian, peneliti melakukan penyusunan instrumen tes, pemilihan media, pemilihan format dan perancangan awal media pembelajaran sesuai dengan prinsip-prinsip perancangan media pembelajaran berdasarkan teori beban kognitif. Terakhir, media pembelajaran divalidasi oleh dua orang dosen Pendidikan Matematika. Jika media dikategorikan valid, maka media dapat diujicobakan kepada subjek untuk melihat kepraktisan dan efektivitas media.

Teknik analisis data dilakukan melalui penskoran dari para ahli dan pengamat dengan indikator-indikator yang terdapat pada instrumen penilaian dengan rentang $1-4$ ( 1 = tidak sesuai, $2=$ cukup sesuai, $3=$ sesuai, $4=$ sangat sesuai). Langkahlangkah analisis data, meliputi (1) skor hasil validasi media pembelajaran akan dihitung dan melalakukan perbaikan sesuai saran ahli. Jika skor validasi, $\bar{V} \geq 3$ maka akan dilanjutkan ke ujicoba; (2) skor kepraktisan dinilai oleh pengamat saat ujicoba media. Jika $\bar{P} \geq 3$ maka media dikategorikan praktis; (3) melihat hasil efektivitas media melalui pengamatan aktivitas siswa. Jika skor $\bar{A} \geq 3$ (kategori: baik) maka media dikategorikan efektif; (4) menyajikan data dalam bentuk narasi; (5) menyimpulkan hasil penelitian. 


\section{HASIL \\ Tahap Define (Pendefenisian)}

Tahap ini bertujuan untuk mendefenisikan masalah yang menjadi dasar pengembangan media pembelajaran interaktif untuk siswa tunarungu. Pada tahap ini terdiri dari kegiatan-kegiatan yang dilakukan, sebagai berikut.

\section{Analisis Awal-Akhir}

Peneliti melakukan analisis terhadap kurikulum matematika pada materi luas dan keliling bangun datar, buku siswa, teori-teori yang relevan serta wawancara terhadap guru untuk mengetahui bentuk pembelajaran di kelas. Dari kegiatan analisis yang dilakukan maka diperoleh sebagai berikut.

Pertama, materi luas dan keliling bangun datar terdapat pada kompetensi dasar sebagai berikut:

3.3 Memahami keliling dan luas bila unsur-unsur diketahui.

4.3 Menghitung keliling dan luas bangun datar bila unsur-unsur bangun datar diketahui.

Berdasarkan kompetensi dasar, maka peneliti menurunkan menjadi beberapa indikator sebagai berikut:

3.3.1 Membangun konsep luas dan keliling bangun datar.

3.3.2 Menemukan rumus keliling dan luas persegi panjang.

3.3.3 Menemukan rumus keliling dan luas persegi.

3.3.4 Menemukan rumus keliling dan luas segitiga.

4.3.1 Menghitung luas dan keliling bangun datar (persegi panjang, persegi dan segitiga).

4.3.2 Menerapkan konsep luas dan keliling bangun datar (persegi panjang, persegi dan segitiga).

Kedua, buku siswa (matematika siswa tunarungu kelas XI Kemendikbud K-13) yang digunakan tidak mengonstruk pengetahuan, namun lebih kepada pemberian rumus luas dan keliling bangun datar untuk diterapkan ke soal-soal matematika.

1) Beberapa teori yang menjadi acuan peneliti dan mendasari melakukan pengembangan media pembelajaran ialah:

a. Rendahnya kemampuan bahasa dan komunikasi siswa tunarungu dalam pembelajaran matematika. (Kelly \& Gaustad, 2007).

b. Siswa tunarungu memiliki kemampuan matematika/problem solving yang lebih rendah. (Ariapooran, 2017 \& Marschark dkk., 2015).

c. Kuranganya motivasi siswa tunarungu untuk belajar matematika (Ariapooran, 2017).

2) Guru menyatakan bahwa untuk mengajar materi luas dan keliling bangun datar belum menggunakan media pembelajaran interaktif. Biasanya guru menjelaskan materi melalui alat peraga atau gambar pada layar proyektor.

\section{Analisis Siswa}

Kemampuan matematika siswa pada materi luas dan keliling bangun datar masih rendah. Peneliti memberikan soal soal rutin untuk menentukan luas dan keliling bangun datar. Hasilnya, siswa belum mampu menjawab soal tersebut dengan baik khususnya pada bangun datar segitiga. Siswa beralasan bahwa mereka tidak mengingat rumus luas dan keliling pada bangun datar yang dimaksud.

\section{Analisis Konsep}

Peneliti merumuskan cakupan konten yang akan dipelajari siswa selama pembelajaran yang meliputi apersepsi berisi konsep dasar bangun datar (persegi panjang, persegi dan segitiga), materi pendahuluan (konsep keliling dan luas bangun datar), materi inti (menemukan luas dan keliling persegi panjang, persegi dan segitiga), latihan dan quiz berbentuk pilihan ganda.

\section{Analisis Tugas}

Peneliti menyusun konten media pembelajaran melalui pencarian sumber materi pembelajaran dan soal-soal, menyusun materi secara bertahap melalui model pembelajaran discovery learning dan teori-teori yang terkait dengan perancangan media pembelajaran khususnya siswa tunarungu.

\section{Spesifikasi Tujuan Pembelajaran}

Melalui aktivitas pembelajaran berdasarkan model pembelajaran discovery learning berbantuan media pembelajaran interaktif, siswa dapat:

3.3.1.1 Menjelaskan konsep keliling dan luas bangun datar melalui contoh dan bukan contoh konsep pada suatu masalah.

3.3.1.2 Menjelaskan konsep keliling bangun datar melalui animasi menghitung seluruh panjang sisi bangun datar pada suatu masalah.

3.3.1.3 Menjelaskan konsep luas bangun datar melalui satuan luas (satuan persegi) pada suatu masalah.

3.3.2.1 Menjelaskan rumus luas dan keliling persegi panjang dari percobaan-percobaan dengan beberapa bentuk persegi panjang yang berbeda.

3.3.3.1 Menjelaskan rumus luas dan keliling persegi dari percobaan-percobaan dengan beberapa bentuk persegi yang berbeda. 
3.3.4.1 Menjelaskan rumus luas dan keliling segitiga dari percobaan-percobaan dengan beberapa bentuk segitiga yang berbeda dan animasi luas segitiga.

4.3.1.1 Jika siswa diminta menentukan luas dan keliling suatu bangun datar, siswa dapat menggunakan rumus yang ditemukannya.

4.3.2.1 Jika diberikan permasalahan mengenai luas dan keliling suatu bangun datar, siswa dapat menyelesaikan permasalahan dengan tepat.

\section{Tahap Design (Perancangan)}

Pada tahap design, peneliti mulai merancang media pembelajaran interaktif untuk menghasilkan draf awal untuk siswa tunarungu kelas XI SMALB YPTB Malang. Beberapa kegiatan yang dilakukan pada tahap design, meliputi (a) penyusunan tes beracuan kriteria, (b) pemilihan media presentasi, (c) pemilihan format, dan (d) perancangan awal.

\section{Penyusunan Tes Beracuan Kriteria}

Tahap ini bertujuan untuk menyusun alat evaluasi produk hasil pengembangan. Instrumen penilaian yang disusun ialah (1) lembar validasi media pembelajaran, (2) lembar kepraktisan media, (3) lembar pengamatan aktivitas siswa.

\section{Pemilihan Media Presentasi}

Tahap ini bertujuan untuk memilih media yang sesuai untuk menyajikan materi luas dam keliling bangun datar untuk siswa tunarungu. Proses penyusunan media disusun berdasarkan analisis konsep, tugas dan tujuan pembelajaran. Media persentasi yang digunakan berisikan halaman-halaman interaktif dengan bantuan Macromedia Flash karena software ini mampu menyajikan narasi, gambar dan animasi yang interaktif bagi siswa tunarungu.

\section{Pemilihan Format}

Rencana Pelaksanaan Pembelajaran disusun terlebih dahulu agar kegiatan lebih terarah. Peneliti memilih format sesuai dengan Rencana Pelaksanaan Pembelajaran. Media pembelajaran berisikan apersepsi, materi, latihan dan quiz.

\section{Perancangan Awal}

Pada saat pembuatan draf awal media pembelajaran interaktif, ada beberapa kegiatan yang dilakukan, meliputi (1) menyesuaikan materi dan soal-soal latihan/quiz yang terdapat pada media pembelajaran pada indikator yang akan dicapai; (2) merancang materi, gambar dan animasi yang akan dimasukkan ke media pembelajaran; (3) mengatur format media pembelajaran interaktif sesuai dengan model discovery learning.

Media pembelajaran terdiri dari pendahuluan (data siswa, apersepsi/prasyarat, materi pendahuluan, kompetensi dasar/indikator pembelajaran, dan petunjuk penggunaan), inti (materi luas dan keliling persegi panjang, persegi dan segitiga) dan penutup (kesimpulan dan latihan). Media pembelajaran dibuat sesuai dengan prinsip-prinsip perancangan media pembelajaran yang dijelaskan pada tabel 1 .

\section{Tabel 1. Penerapan Prinsip Perancangan Media Berdasarkan Teori Beban Kognitif}

\begin{tabular}{lll}
\hline Tujuan & Prinsip & \multicolumn{1}{c}{ Bentuk Penerapan } \\
\hline $\begin{array}{l}\text { Mengurangi } \\
\text { Beban } \\
\text { Kognitif } \\
\text { extranous }\end{array}$ & Prinsip koheren & $\begin{array}{l}\text { Media pembelajaran ini menghilangkan materi yang tidak berkaitan. Media } \\
\text { pembelajaran hanya fokus pada materi luas dan keliling bangun datar khususnya persegi } \\
\text { panjang, persegi dan segitiga. Pada materi apersepsi hanya membahas pengertian bangun } \\
\text { datar tersebut tanpa membahas sifat-sifatnya untuk membantu siswa memahami konsep } \\
\text { awal. }\end{array}$ \\
\cline { 2 - 3 } & Prinsip redunansi & $\begin{array}{l}\text { Menghilangkan teks yang berlebihan dan membuat siswa bingung. Mengurangi banyak } \\
\text { kata-kata yang membuat siswa sulit untuk mengerti. }\end{array}$ \\
\cline { 2 - 3 } & Prinsip signalisasi & $\begin{array}{l}\text { Media memiliki sinyal yang baik untuk mengolah materi dengan menyajikan } \\
\text { simbol/tombol yang memudahkan siswa fokus pada materi. Media pembelajaran } \\
\text { memiliki tombol-tombol yang mengarahkan siswa pada materi yang ingin dituju. }\end{array}$ \\
\cline { 2 - 3 } & Prinsip keterdekatan & $\begin{array}{l}\text { Pada setiap halaman akan disediakan teks, gambar dan animasi yang berhubungan } \\
\text { dengan pembahasan secara utuh tanpa dibahas di halaman selanjutnya. }\end{array}$ \\
\cline { 2 - 3 } & waktu & $\begin{array}{l}\text { Posisi teks, gambar dan animasi di suatu pembahasan diletakkan pada halaman yang } \\
\text { sama tanpa berlanjut ke halaman selanjutnya. }\end{array}$ \\
\cline { 2 - 3 } $\begin{array}{l}\text { Mengontrol } \\
\text { beban } \\
\text { kognitif } \\
\text { instrinsic }\end{array}$ & Keterdekatan Ruang & $\begin{array}{l}\text { Pada media pembelajaran, topik luas dan keliling bangun datar dipecah menjadi } \\
\text { pembahasan-pembahasan yang dapat dikontrol siswa setiap halamannya. }\end{array}$ \\
\cline { 2 - 3 } & Prinsip pretraining & $\begin{array}{l}\text { Media menyajikan materi prasyarat dan juga memastikan penguasaan materi prasyarat } \\
\text { melalui latihan. Sebelum masuk ke materi inti (luas dan keliling persegi panjang, persegi } \\
\text { dan segitiga), media pembelajaran menghadapkan siswa dengan konsep persegi panjang, } \\
\text { persegi dan segitiga. }\end{array}$ \\
\hline
\end{tabular}


Tabel 1. Penerapan Prinsip Perancangan Media Berdasarkan Teori Beban Kognitif (Lanjutan)

\begin{tabular}{|c|c|c|}
\hline Tujuan & Prinsip & $\begin{array}{l}\text { Bentuk Penerapan } \\
\end{array}$ \\
\hline & Prinsip modalitas & $\begin{array}{l}\text { Menyajikan materi dengan narasi, gambar dan animasi yang berhubungan. Media } \\
\text { pembelajaran menyajikan materi melalui narasi, gambar dan animasi yang } \\
\text { berhubungan pada setiap halamannya. }\end{array}$ \\
\hline \multirow{5}{*}{$\begin{array}{l}\text { Membantu } \\
\text { proses beban } \\
\text { kognitif } \\
\text { germane }\end{array}$} & Prinsip multimedia & $\begin{array}{l}\text { Media pembelajaran menyajikan materi melalui narasi, gambar dan animasi yang } \\
\text { menarik bagi siswa sesuai dengan tingkatnya. }\end{array}$ \\
\hline & $\begin{array}{l}\text { Prinsip perbedaan } \\
\text { individual }\end{array}$ & $\begin{array}{l}\text { Menyajikan materi sesuai dengan karakteristik dan kemampuan siswa. Materi } \\
\text { siswa tunarungu berbeda dengan siswa normal dengan tingkat yang sama. Materi } \\
\text { keliling dan luas bangun datar yang dipelajari oleh siswa tunarungu pada kelas XI. }\end{array}$ \\
\hline & $\begin{array}{l}\text { Prinsip aktivitas } \\
\text { yang terarah }\end{array}$ & $\begin{array}{l}\text { Menyusun media yang menghasilkan pengalaman belajar. Pada media } \\
\text { pembelajaran menggunakan model pembelajaran discovery learning. }\end{array}$ \\
\hline & $\begin{array}{l}\text { Prinsip umpan } \\
\text { balik }\end{array}$ & $\begin{array}{l}\text { Memberikan umpan balik atas respons siswa. Media pembelajaran menghasilkan } \\
\text { respons atas setiap jawaban siswa. }\end{array}$ \\
\hline & Prinsip refleksi & $\begin{array}{l}\text { Memberi kesempatan siswa untuk mengkaji ulang pengalaman belajar. Media } \\
\text { pembelajaran menghadirkan kesempatan siswa untuk mengkaji ulang aktivitas- } \\
\text { aktivasnya dan kesimpulan pembelajaran. }\end{array}$ \\
\hline
\end{tabular}

\section{Tahap Develop (Pengembangan) \\ Hasil Validasi Media Pembelajaran}

Media pembelajaran interaktif yang sudah dirancang akan divalidasi oleh dua orang ahli media. Hasil validasi media dapat ditunjukkan pada tabel 2. Pada tabel validasi media pembelajaran, skor validasi ialah $\mathrm{V}^{-}=3,6$. Berdasarkan kriteria kevalidan media pembelajaran, jika $V \geqslant 3$ maka media pembelajaran dikategorikan valid. Sehingga, media pembelajaran layak digunakan dengan beberapa komentar dan saran dari para ahli yaitu menambahkan materi pendahuluan berupa konsep luas dan keliling ditambahkan melalui narasi dan memperbaiki gambar-gambar pada media agar lebih konstektual seperti contoh pada gambar 1.

Tabel 2. Hasil Validasi Media Pembelajaran Interaktif

\begin{tabular}{|c|c|c|c|}
\hline \multirow{2}{*}{ No } & \multirow{2}{*}{ Aspek } & \multicolumn{2}{|c|}{ Skor Penilaian } \\
\hline & & $\mathbf{V}_{1}$ & $\mathbf{V}_{2}$ \\
\hline \multirow[t]{6}{*}{$\mathbf{I}$} & Isi Media Pembelajaran & & \\
\hline & $\begin{array}{l}\text { 1. Media pembelajaran dapat membantu siswa membangun konsep luas dan } \\
\text { keliling bangun datar. }\end{array}$ & 3 & 4 \\
\hline & $\begin{array}{l}\text { 2. Media pembelajaran dapat membantu siswa menemukan rumus luas dan } \\
\text { keliling bangun datar secara terbimbing. }\end{array}$ & 4 & 4 \\
\hline & $\begin{array}{l}\text { 3. Aktivitas yang diberikan memungkinkan adanya interaksi yang positif } \\
\text { antara siswa dengan media pembelajaran. }\end{array}$ & 4 & 4 \\
\hline & $\begin{array}{l}\text { 4. Kegiatan yang terdapat dalam penggunaan media pembelajaran sesuai } \\
\text { dengan tujuan pembelajaran. }\end{array}$ & 3 & 4 \\
\hline & 5. Media pembelajaran tidak menimbulkan ambigu dan kebingungan. & 4 & 3 \\
\hline \multirow[t]{5}{*}{ II } & Gambar dan animasi & & \\
\hline & $\begin{array}{l}\text { 1. Media pembelajaran disertai dengan gambar dan animasi yang sesuai } \\
\text { dengan materi atau konsep yang dibahas. }\end{array}$ & 4 & 4 \\
\hline & $\begin{array}{l}\text { 2. Gambar dan animasi yang digunakan memperjelas dan berhubungan } \\
\text { dengan materi pembelajaran. }\end{array}$ & 4 & $\begin{array}{l}4 \\
3\end{array}$ \\
\hline & 3. Gambar dan animasi yang disajikan menarik. & 4 & \\
\hline & 4. Gambar dan animasi yang disajikan sesuai dengan siswa tunarungu & 4 & 3 \\
\hline \multirow[t]{3}{*}{ III } & Kegunaan Media Pembelajaran & & \\
\hline & $\begin{array}{l}\text { 1. Dapat digunakan untuk membantu siswa dalam mencapai tujuan } \\
\text { pembelajaran. }\end{array}$ & 3 & 4 \\
\hline & $\begin{array}{l}\text { 2. Dapat memberikan respons langsung kepada siswa sehingga adanya } \\
\text { interaksi langsung dengan media pembelajaran. }\end{array}$ & 3 & 4 \\
\hline \multirow[t]{6}{*}{ IV } & Bahasa dan simbol & & \\
\hline & 1. Bahasa yang digunakan komunikatif dan sederhana. & 4 & 3 \\
\hline & $\begin{array}{l}\text { 2. Tampilan simbol (warna, jenis font dan ukuran font) yang digunakan } \\
\text { menarik dan mempermudah siswa menggunakan media. }\end{array}$ & 4 & 4 \\
\hline & Jumlah & 51 & 52 \\
\hline & Rata-rata & 3,64 & 3,71 \\
\hline & Rata-rata total $(\bar{V})$ & & \\
\hline
\end{tabular}




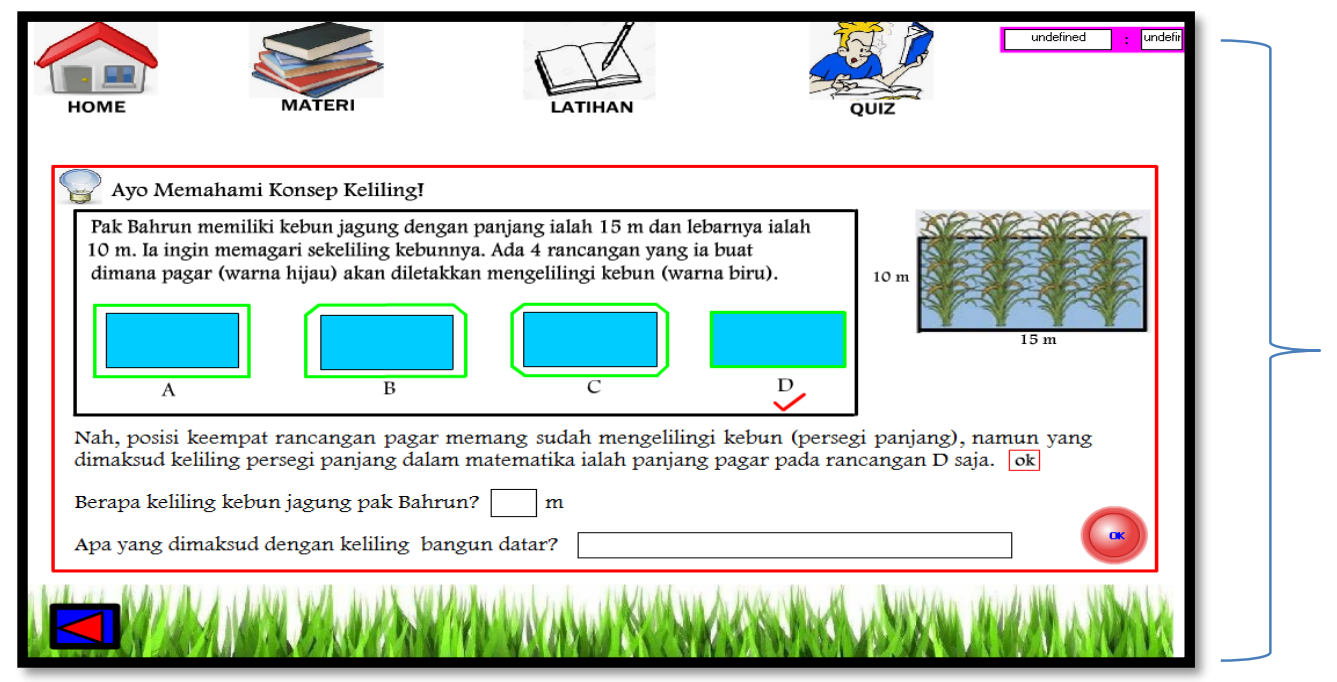

Materi pendahuluan disampaikan melalui narasi dan gambar yang konstektual.

\section{Gambar 1. Contoh Revisi Media Pembelajaran Interaktif}

\section{Hasil Penilaian Kepraktisan}

Media pembelajaran interaktif yang sudah dirancang akan dinilai tingkat kepraktisannya saat digunakan oleh siswa tunarungu. Hasil penilaian kepraktisan oleh pengamat dapat dilihat pada tabel 3.

\section{Hasil Penilaian Efektivitas}

Efektivitas dinilai dari aktivitas siswa selama menggunakan media pembelajaran yang diamati dan dinilai oleh pengamat. Hasil penilaian aktivitas siswa dapat dilihat pada tabel 4.

Tabel 3. Hasil Penilaian Kepraktisan

\begin{tabular}{|c|c|c|c|c|}
\hline \multirow[t]{2}{*}{ No } & \multirow[t]{2}{*}{ Pernyataan } & \multicolumn{3}{|c|}{ Pertemuan } \\
\hline & & $\mathbf{I}$ & II & III \\
\hline 1 & $\begin{array}{l}\text { Persiapan untuk menggunakan media interaktif tidak } \\
\text { menyulitkan dan merepotkan bagi siswa. }\end{array}$ & 3 & 3 & 3 \\
\hline 2 & $\begin{array}{l}\text { Petunjuk penggunaan membantu } \\
\text { menggunakan media interaktif. }\end{array}$ & 3 & 3 & 4 \\
\hline 3 & Tulisan pada media interaktif mudah untuk dibaca. & 4 & 4 & 3 \\
\hline 4 & Warna pada media interaktif cocok untuk dilihat. & 4 & 4 & 3 \\
\hline 5 & Kalimat pada media interaktif mudah untuk dipahami. & 3 & 3 & 3 \\
\hline 6 & $\begin{array}{l}\text { Tombol-tombol petunjuk pada media interaktif mudah } \\
\text { digunakan oleh siswa. }\end{array}$ & 4 & 3 & 4 \\
\hline 7 & Gambar yang tersedia pada media interaktif jelas. & 3 & 3 & 3 \\
\hline 8 & $\begin{array}{l}\text { Animasi yang tersedia pada media interaktif dapat } \\
\text { membantu siswa memahami konsep dan rumus. }\end{array}$ & 3 & 3 & 3 \\
\hline 9 & Siswa mudah untuk mengetik dan memilih jawaban. & 4 & 4 & 3 \\
\hline 10 & Hasil evaluasi bisa didapatkan langsung dengan mudah. & 3 & 4 & 4 \\
\hline & Jumlah & 34 & 34 & 33 \\
\hline & Rata-rata & 3,4 & 3,4 & 3,3 \\
\hline & Rata-rata total $(\bar{P})$ & & 3,37 & \\
\hline
\end{tabular}

Pada tabel kepraktisan media pembelajaran, skor kepraktisan ialah $\bar{P}=3,37$. Berdasarkan kriteria kepraktisan media pembelajaran, jika $\bar{P} \geq 3$ maka media pembelajaran dikategorikan praktis. Jadi, media pembelajaran praktis digunakan bagi siswa 
Tabel 4. Hasil Pengamatan Aktivitas Siswa

\begin{tabular}{|c|c|c|c|c|}
\hline \multirow{2}{*}{ No } & \multirow{2}{*}{ Aspek yang diamati } & \multicolumn{3}{|c|}{ Pertemuan } \\
\hline & & $\mathbf{I}$ & II & II \\
\hline 1. & Siswa mengikuti kegiatan pendahuluan/apersepsi. & 3 & 3 & 3 \\
\hline 2. & $\begin{array}{l}\text { Siswa mendengarkan instruksi dari guru, membaca penggunaan media } \\
\text { pembelajaran dan menanyakan hal yang kurang dimengerti. }\end{array}$ & 3 & 4 & 3 \\
\hline 3. & $\begin{array}{l}\text { Siswa melaksanakan petunjuk media dan mengendalikan media } \\
\text { pembelajaran interaktif. }\end{array}$ & 4 & 4 & 4 \\
\hline 4. & $\begin{array}{l}\text { Siswa mengeksplorasi permasalahan menggunakan media pembelajaran } \\
\text { interaktif }\end{array}$ & 3 & 3 & 4 \\
\hline 5. & $\begin{array}{l}\text { Siswa menggunakan media pembelajaran interaktif untuk } \\
\text { mengkonstruksi pengetahuan matematika. }\end{array}$ & 4 & 3 & 4 \\
\hline 6. & $\begin{array}{l}\text { Siswa melakukan percobaan untuk membantu mengkonstruksi } \\
\text { pengetahuan. }\end{array}$ & 3 & 3 & 3 \\
\hline 7. & Siswa menggeneralisasi konsep/rumus melalui percobaan-percobaan. & 3 & 3 & 3 \\
\hline 8. & $\begin{array}{l}\text { Siswa dapat mencari suatu konsep/rumus dan mendapat kesempatan } \\
\text { untuk memberikan kesimpulan berdasarkan aktivitas dan masalah- } \\
\text { masalah yang diberikan. }\end{array}$ & 3 & 3 & 4 \\
\hline 9. & Siswa menguji penguasaan materi dengan mengerjakan latihan dan quiz. & 3 & 4 & 3 \\
\hline 10. & $\begin{array}{l}\text { Siswa bersama guru menyimpulkan materi yang dipelajari dan } \\
\text { mengevaluasi pembelajaran. }\end{array}$ & 3 & 4 & 3 \\
\hline & Jumlah & 32 & 34 & 32 \\
\hline & Rata-rata & 3,2 & 3,4 & 3,2 \\
\hline & Rata-rata total $(\bar{A})$ & & 3,27 & \\
\hline
\end{tabular}

\section{PEMBAHASAN}

Penelitian pengembangan yang dilakukan menghasilkan media pembelajaran interaktif untuk siswa tunarungu pada materi luas dan keliling bangun datar melalui model pengembangan 4D yang dimodifikasi. Media pembelajaran interaktif yang dihasilkan memenuhi kriteria valid, efektif dan praktis. Kriteria valid diperoleh berdasarkan uji validitas media pembelajaran, kriteria praktis diperoleh dari hasil observasi pengamat mengenai penggunaan media oleh siswa tunarungu. Kriteria keefektifan diperoleh dari hasil observasi aktivitas siswa.

Pada uji validitas oleh dua orang ahli melalui lembar validasi media pembelajaran, skor validasi yang diperoleh ialah $\bar{V}_{m}=3,68$ dengan kriteria valid. Beberapa komentar dan saran yang diberikan para ahli dan ditindaklanjuti ialah mengenai isi media pembelajaran, ahli memberi saran agar penjelasan membangun konsep luas dan keliling bangun datar melalui narasi. Bantuan visual dan kata-kata yang sederhana dapat membantu siswa untuk memahami narasi lebih mudah (Mich dkk, 2013) Kemudian, pada gambar dan animasi yang digunakan pada media pembelajaran, beberapa gambar yang kurang konstektual dicari kembali. Terakhir, beberapa perbaikan script perlu dilakukan agar media pembelajaran dapat berjalan semestinya.

Materi pembelajaran siswa tunarungu memiliki perbedaan dengan siswa normal pada umumnya. Kesenjangan prestasi antara siswa yang sulit mendengar dan siswa normal tetap besar (Qi \& Mitchell, 2012). Terdapat soal-soal untuk menguji pemahaman siswa terhadap materi. Soal-soal tersebut disesuaikan dengan tingkat pemahaman siswa yang sampai ke tingkat penerapan konsep dan rumus matematika.

Materi luas dan keliling bangun datar disajikan dalam bentuk teks, gambar dan animasi. Agar tidak menambah beban kognitif, materi tidak memuat materi tambahan yang membuat kompleks. Materi berisi konsep dan rumus luas dan keliling bangun datar yang dimuat dengan sederhana. Pada apersepsi hanya disampaikan konsep dasar persegi panjang, persegi dan segitiga yang akan berhubungan pada materi inti. Media ini juga menampilkan narasi hanya pada saat pemberian masalah ke siswa untuk mengurangi materi tambahan. Untuk mengurangi kata-kata pada media juga ditampilkan teks/narasi singkat dan sederhana (Shelton \& Parlin, 2016; Techaraungrong dkk., 2017). Selain itu, media juga menghasilkan pengalamanpengalaman belajar melalui pertanyaan-pertanyaan singkat. Penggunaan simbol bagi siswa juga mengalami kesulitan misalkan saja dalam bentuk variabel yang digunakan untuk menggeneralisasi rumus. Kesulitan matematika siswa tunarungu juga terdapat pada penggunaan variabel (Hyde dkk., 2003).

Siswa tunarungu memang banyak terkendala pada bahasa. Siswa banyak kurang memahami bahasa yang terlalu kompleks sehingga dibutuhkan bahasa yang sederhana dan langsung ke tujuan pertanyaan. Mich dkk. (2013) menyatakan bahwa cerita yang disederhanakan dan diilustrasikan, memiliki indeks keterbacaan yang lebih tinggi, membuat latihan pemahaman lebih mudah. Alat bantu visual dan penyederhanaan teks memang membantu anak-anak lebih mudah memahami cerita yang disederhanakan, diilustrasikan dengan gambar dan diperluas dengan definisi, ternyata lebih efektif untuk pemahaman membaca siswa tunarungu (Mich dkk., 2013). 
Media menghasilkan teks, gambar dan animasi. Pelajar tunarungu dapat memiliki kepekaan terhadap sinyal visual dan kemampuan untuk menghadapi perbedaan (Borgna dkk., 2011). Penggunaan strategi untuk menyediakan banyak gambar yang lebih lengkap tentang penyelesaian masalah di dalam pendidikan siswa tunarungu merupakan hal yang tepat (Lang \& Pagliaro, 2007). Struktur cerita juga seharusnya dirancang dengan hati-hati untuk menghindari kebingungan dan kebosanan pada pembaca tunarungu, terutama karena tidak adanya gambar yang membantu mengontekstualisasikan peristiwa dan membaca informasi (Mich dkk., 2013).

Uji kepraktisan media diisi oleh pengamat yang mengobservasi penggunaan media pembelajaran oleh siswa tunarungu. Skor kepraktisan yang diperoleh ialah $\bar{P}=3,37$ dengan kriteria praktis. Pengamat memberi saran untuk menambahkan video/animasi yang membantu siswa dalam memahami materi. Pada saat pembelajaran, siswa memang sedikit kesulitan dalam memahami bahasa dalam media pembelajaran. Kelemahan siswa tidak hanya pada ketidakmapuan mendengar tapi juga kesulitan membaca (Techaraungrong dkk., 2017). Setiap penjelasan materi memang sebaiknya dijelaskan secara sederhana dan dibantu dengan animasi yang sesuai.

Pada uji keefektifan dilihat dari penilaian pengamatan aktivitas siswa. Aktivitas siswa berada pada skor $\bar{A}=$ 3,27 dengan kategori baik. Meskipun skor sudah baik, namun beberapa hal yang menjadi perhatian ialah penyajian teks, gambar dan animasi yang perlu untuk diperbaiki lagi. Hal ini penting mengingat kurangnya motivasi siswa tunarungu dalam belajar matematika.

\section{SIMPULAN}

Berdasarkan proses penelitian yang dilakukan, ada beberapa karakteristik yang didapatkan mengenai media pembelajaran untuk siswa tunarungu. Pada aspek materi, siswa lebih butuh materi yang disampaikan secara bertahap dan tingkat pemahaman siswa terhadap materi dapat menuju ke tingkat penerapan tapi tidak sampai ke tingkat analisis. Penyajian media siswa tunarungu membutuhkan gambar/animasi yang konstektual untuk setiap narasi dan gambar/animasi seharusnya dapat memperjelas materi yang diajarkan. Selain itu, penggunaan teks seharusnya lebih sederhana dan tidak membingungkan siswa. Untuk meningkatkan sikap dan motivasi siswa tunarungu pada matematika, dapat ditambahkan penyajian media pembelajaran interaktif dan menarik yang dapat mengakomodasi kemampuan siswa tunarungu.

Pada penelitian ini dihasilkan media pembelajaran yang valid dengan skor $\bar{V}=3,68$, praktis dengan skor $\bar{P}=3,37$ dan efektif dengan skor $\bar{A}=3,27$. Selanjutnya, peneliti juga menyarankan beberapa hal untuk penyempurnaan penelitian ini, yakni (1) melakukan studi lebih mendalam mengenai aspek kebahasaan siswa tunarungu pada media pembelajaran matematika, (2) Penelitian lebih lanjut mengenai penggunaan teks, gambar dan animasi yang sesuai pada media intraktif untuk siswa tunarungu, dan (3) melakukan proses wawancara untuk menganalisis lebih jauh mengenai karekteristik media pembelajaran interaktif untuk siswa tunarungu.

\section{DAFTAR RUJUKAN}

Ariapooran, S. (2017). Mathematics Motivation, Anxiety, and Performance in Female Deaf/Hard-of-Hearing and Hearing Students. Communication Disorders Quarterly, 38(3), 172-178. https://doi.org/10.1177/1525740116681271

Borgna, G., Convertino, C., Marschark, M., Morrison, C., \& Rizzolo, K. (2011). Enhancing Deaf Students' Learning from Sign Language and Text: Metacognition, Modality, and the Effectiveness of Content Scaffolding. Journal of Deaf Studies and Deaf Education, 16(1), 79-100. https://doi.org/10.1093/deafed/enq036

Cavender, A. C., Bigham, J. P., \& Ladner, R. E. (2009). ClassInFocus: Enabling Improved Visual Attention Strategies for Deaf and Hard of Hearing Students. 67. https://doi.org/10.1145/1639642.1639656

Chen, Y.-T. (2014). A Study to Explore The Effects of Self-Regulated Learning Environment for Hearing-Impaired Students: A Self-Regulated Learning Environment. Journal of Computer Assisted Learning, 30(2), 97-109. https://doi.org/10.1111/jcal.12023

Dukes, C \& Smith, M. (2009). Cara Menangani Anak Berkebutuhan Khusus, Edisi Terjemahan. Jakarta: PT. Indeks.

Hyde, M., Zevenbergen, R., \& Power, D. J. (2003). Deaf and Hard of Hearing Students' Performance on Arithmetic Word Problems. American Annals of the Deaf, 148(1), 56-64. https://doi.org/10.1353/aad.2003.0003

Kelly, R. R., \& Gaustad, M. G. (2006). Deaf College Students' Mathematical Skills Relative to Morphological Knowledge, Reading Level, and Language Proficiency. Journal of Deaf Studies and Deaf Education, 12(1), $25-37$. https://doi.org/10.1093/deafed/en1012

Lang, H., \& Pagliaro, C. (2007). Factors Predicting Recall of Mathematics Terms by Deaf Students: Implications for Teaching. Journal of Deaf Studies and Deaf Education, 12(4), 449-460. https://doi.org/10.1093/deafed/enm021

Marschark, M., Shaver, D. M., Nagle, K. M., \& Newman, L. A. (2015). Predicting the Academic Achievement of Deaf and Hard-of-Hearing Students From Individual, Household, Communication, and Educational Factors. Exceptional Children, 81(3), 350-369. https://doi.org/10.1177/0014402914563700

Mayer, R. E. (2014). Cognitive Theory of Multimedia Learning. In R. Mayer (Ed.), The Cambridge Handbook of Multimedia Learning (2nd ed., pp. 43-71). https://doi.org/10.1017/CBO9781139547369.005 
Mayer, R. E., \& Moreno, R. (2003). Nine Ways to Reduce Cognitive Load in Multimedia Learning. Educational Psychologist, 38(1), 43-52. https://doi.org/10.1207/S15326985EP3801_6

Mich, O., Pianta, E., \& Mana, N. (2013). Interactive Stories and Exercises with Dynamic Feedback for Improving Reading Comprehension Skills in Deaf Children. Computers \& Education, 65, 34-44. https://doi.org/10.1016/j.compedu.2013.01.016

National Council of Teachers of Mathematics (Ed.). (2000). Principles and Standards for School Mathematics. Reston, VA: National Council of Teachers of Mathematics.

Passig, D. (2000). Enhancing the Induction Skill of Deaf and Hard-of-Hearing Children with Virtual Reality Technology. Journal of Deaf Studies and Deaf Education, 5(3), 277-285. https://doi.org/10.1093/deafed/5.3.277

Qi, S., \& Mitchell, R. E. (2012). Large-Scale Academic Achievement Testing of Deaf and Hard-of-Hearing Students: Past, Present, and Future. Journal of Deaf Studies and Deaf Education, 17(1), 1-18. https://doi.org/10.1093/deafed/enr028

Seo, Y.-J., \& Woo, H. (2010). The Identification, Implementation, and Evaluation of Critical User Interface Design Features of Computer-Assisted Instruction Programs in Mathematics for Students with Learning Disabilities. Computers \& Education, 55(1), 363-377. https://doi.org/10.1016/j.compedu.2010.02.002

Shelton, B. E \& Parlin, M. A. (2016). Teaching Math to Deaf/Hard-of-Hearing (DHH) Children Using Mobile Games: Outcomes with Student and Teacher Perspective: International Journal of Mobile and Blended Learning, 8(1),1-17.

Techaraungrong, P., Suksakulchai, S., Kaewprapan, W., \& Murphy, E. (2017). The Design and Testing of Multimedia for Teaching Arithmetic to Deaf Learners. Education and Information Technologies, 22(1), 215-237. https://doi.org/10.1007/s10639-015-9441-1

World Health Organization (WHO). (2019). Deafness and Hearing Loss. Diambil dari https://www.who.int/news-room/factsheets/detail/deafness-and-hearing-loss 